\title{
The usefulness of conventional and echo colour Doppler sonography in the differential diagnosis of toxic multinodular goitres
}

\author{
F Boi, M Loy ${ }^{1}$, M Piga $^{2}$, A Serra ${ }^{2}$, F Atzeni and S Mariotti \\ Endocrinology, ${ }^{1}$ Radiology and ${ }^{2}$ Nuclear Medicine, Department of Medical Sciences, University of Cagliari, Cagliari, Italy \\ (Correspondence should be addressed to S Mariotti, Endocrinology, Department of Medical Sciences, University of Cagliari, Via San Giorgio 12, \\ I-09124 Cagliari, Italy; Email: mariotti@pacs.unica.it)
}

\begin{abstract}
Objective: To assess the potential role of conventional sonography and colour flow Doppler (CFD) sonography (CFDS) in the differential diagnosis of toxic multinodular goitres.

Subjects and methods: We investigated 55 patients with untreated hyperthyroidism (24 with typical toxic diffuse goitre of Graves' disease (Group A); 26 with multinodular goitre (Group B); and five with single toxic adenoma (Group C); 22 euthyroid subjects (12 with non-toxic multinodular goitre (Group D) and ten normal subjects (Group E)) were included as controls. In all cases free thyroxine, free tri-iodothyronine, TSH, TSH receptor antibodies (TRAb), anti-thyroperoxidase antibody, anti-thyroglobulin antibodies and anti-thyroid microsomal antibodies were determined and a [99m Tc]pertechnetate thyroid scan was performed.

Results: Patients with toxic multinodular goitre displayed two different CFDS patterns: 18 patients (Group B-1) had nodules with normal vascularity surrounded by diffuse parenchymal hypoechogenicity with markedly increased CFD signal and maximal peak systolic velocity (PSV) (a pattern similar to Group A patients with Graves' disease); eight patients (Group B-2) had increased intra- and perinodular CFD signal and PSV with normal extranodular vascularity (a pattern similar to that found in Group C patients with single toxic adenoma). Patients of Group B-1 showed a proportion of clinically evident thyroid ophthalmopathy, positive TRAb and other thyroid autoantibodies similar to that observed in Group A patients, while no evidence of thyroid autoimmunity was found in Group B-2. Sixteen out of $18(89 \%)$ patients from Group B-1 displayed a scintiscan pattern of diffuse uneven radionuclide distribution, while seven out of eight (87.5\%) of those from Group B-2 had localized uptake in multiple discrete nodules. Taken together, these data strongly suggest that Group B-1 mostly represents patients with the multinodular variant of Graves' disease, while Group B-2 represents patients with non-autoimmune toxic multinodular goitre.

Conclusions: This study shows that combined conventional sonography and CFDS may easily distinguish nodular variants of Graves' disease from non-autoimmune forms of toxic multinodular goitre and confirms the clinical usefulness of this technique in the first-line evaluation of hyperthyroid patients.
\end{abstract}

European Journal of Endocrinology 143 339-346

\section{Introduction}

The pathogenesis of toxic multinodular goitre, also called Marine-Lenhart syndrome $(1,2)$ has been debated in the past. In particular, the question has been raised as to whether, similar to the situation in toxic diffuse goitre of Graves' disease, thyroid autoimmunity and thyroid-stimulating antibody (TSAb) may play a role in the pathogenesis of this disorder (3-11). An important contribution to this topic was provided by Kraiem et al. (8) who clearly identified a subgroup of hyperthyroid patients with a multinodular variant of Graves' disease distinct from those with multiple autonomously functioning nodules. Although in some cases the differential diagnosis between autoimmune and non-autoimmune variants of toxic multinodular goitre may be made on clinical grounds (e.g. the coexistence of toxic multinodular goitre and thyroid ophthalmopathy is diagnostic of Graves' disease), in several cases the two conditions may be difficult to discriminate. Apart from the detection of serum TSAb and other anti-thyroid autoantibodies, an important contribution to the differential diagnosis may derive from the scintiscan (12). Patients with 


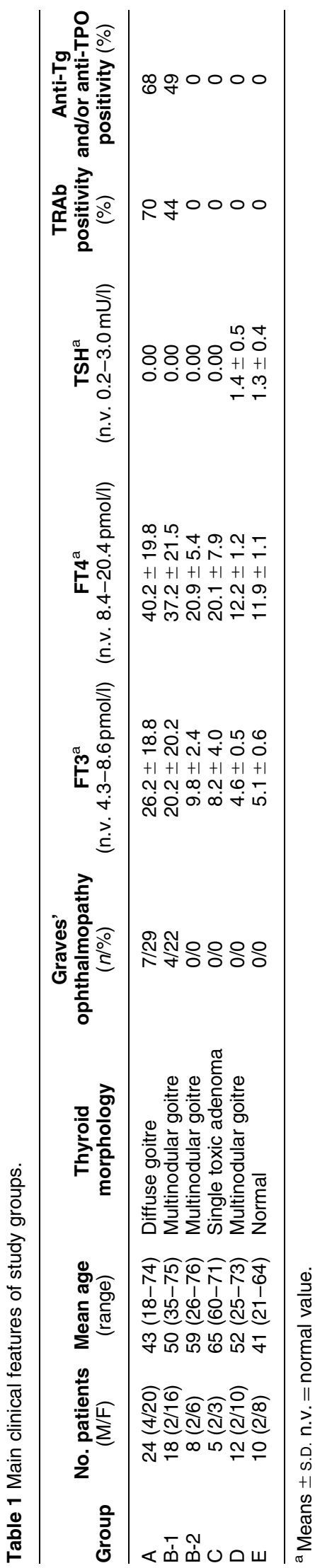

toxic multinodular goitres may display either diffuse but uneven distribution of the radioisotope, or multiple discrete 'hot' nodules surrounded by 'cold' suppressed thyroid tissue. The diffuse pattern is generally observed in the autoimmune variant of toxic multinodular goitre, while the other pattern is more frequent in patients with the non-autoimmune variant, but the scintiscan does not provide a complete discrimination (8).

Conventional sonography and colour flow Doppler (CFD) sonography (CFDS) have been widely used in past years for the morphological and functional characterization of different kinds of hyperthyroid conditions (13). In untreated Graves' disease, the conventional sonographic pattern is typically hypoechogenic and CFDS displays a marked increase in intrathyroidal blood flow (so called 'thyroid inferno') $(14,15)$. This pattern is strictly related to the activity of Graves' disease (16-19) and it is believed to result from TSAb stimulation (15). Unlike with toxic diffuse goitre, very few sonographic studies have been carried out in toxic multinodular goitre. It has been recently reported that CFDS may identify functionally autonomous thyroid 'hot' nodules by their increased intranodular vascularity in both overt and subclinical hyperthyroidism (20). To the best of our knowledge, until now no study has specifically addressed the potential role of conventional sonography and CFDS in the differential diagnosis of the autoimmune and nonautoimmune variants of toxic multinodular goitre.

In the present paper we provide evidence that CFDS is a very sensitive and specific tool for a 'first-line' differential diagnosis between autoimmune and nonautoimmune multinodular goitres.

\section{Subjects and procedures}

\section{Patients}

A total of 55 untreated consecutive hyperthyroid patients were studied. These included 24 patients with typical toxic diffuse goitre of Graves' disease (Group A) and 26 patients with multinodular goitre (Group B). This was a heterogeneous group including four patients with clinically evident Graves' ophthalmopathy, i.e. with an obvious multinodular variant of Graves' disease. However, for the purpose of this investigation, all patients were blindly sub-classified only on the basis of CFDS pattern into B-1 and B-2 Groups (see Tables 1 and 2 and Results for details) by two of us (F B and M L) who were unaware of the presence/absence of eye signs, as well as of scintiscan and thyroid autoantibody assays. All patients of A and B-1 Groups had overt hyperthyroidism with undetectable $(<0.01 \mathrm{mU} / \mathrm{l})$ serum thyrotrophin (TSH) and increased serum free tri-iodothyronine (FT3) (>8.6 pmol/l) and free thyroxine (FT4) $(>20.4 \mathrm{pmol} / \mathrm{l})$. Four out of eight patients of Group B-2 had subclinical hyperthyroidism (undetectable TSH with FT4 and FT3 still within the normal range). 
Table 2 CFD sonographic features of the study groups.

\begin{tabular}{|c|c|c|c|c|c|c|}
\hline $\begin{array}{l}\text { Study } \\
\text { group }(n)\end{array}$ & $\begin{array}{l}\text { Thyroid } \\
\text { volume }^{a}\end{array}$ & Echogenicity & $\begin{array}{c}\text { Parenchymal } \\
\text { vascularization } \\
\text { pattern }\end{array}$ & $\begin{array}{l}\text { Parenchymal PSV } \\
\qquad(\mathrm{cm} / \mathrm{s})^{a}\end{array}$ & $\begin{array}{c}\text { Nodular } \\
\text { vascularization } \\
\text { pattern }\end{array}$ & $\begin{array}{l}\text { Nodular PSV } \\
\qquad(\mathrm{cm} / \mathrm{s})^{\mathrm{a}}\end{array}$ \\
\hline$A(24)$ & $26.2 \pm 16$ & Diffuse hypoechogenicity & III diffuse & $58.6 \pm 3.1^{b}$ & - & - \\
\hline B-1 (18) & $27.5 \pm 14$ & $\begin{array}{l}\text { Extranodular parenchymal } \\
\text { hypoechogenicity }\end{array}$ & III extranodular & $56.1 \pm 3.4^{b}$ & $0-1$ & $12 \pm 2$ \\
\hline B-2 (8) & $46.4 \pm 30$ & $\begin{array}{l}\text { Extranodular parenchymal } \\
\text { normal }\end{array}$ & 0 & $12 \pm 3$ & III & $46 \pm 16^{c}$ \\
\hline C (5) & $26 \pm 3.6$ & $\begin{array}{l}\text { Extranodular parenchymal } \\
\text { normal }\end{array}$ & 0 & $10 \pm 2$ & III & $53 \pm 15^{c}$ \\
\hline D (12) & $38.6 \pm 20$ & Normal & 0 & $13 \pm 4$ & $0-1$ & $13 \pm 3$ \\
\hline$E(10)$ & $12 \pm 5$ & Normal & 0 & $12 \pm 2$ & - & - \\
\hline
\end{tabular}

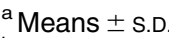

${ }^{\mathrm{b}} P<0.0001$ vs groups $\mathrm{B}-2, \mathrm{C}, \mathrm{D}$ and $\mathrm{E} ;{ }^{\mathrm{c}} P<0.0001$ vs groups $\mathrm{B}-1$ and $\mathrm{D}$.

As controls, five patients with single toxic (three) and pre-toxic (two) adenoma (Group C), 12 euthyroid patients with non-toxic multinodular goitre (Group D) and ten normal euthyroid subjects (Group E) were included. The main clinical and biochemical features of the patients and controls are reported in Table 1.

\section{Conventional sonography and CFDS}

Conventional sonography and CFDS were performed using an Acuson 128 XP 10 colour Doppler system (Acuson Co., Mountain View, CA, USA) with a $7.5 \mathrm{MHz}$ linear electronic transducer. In all cases the examination included first a conventional grey-scale sonography, followed by CFDS. Thyroid volume was calculated by the ellipsoid method (width $\times$ length $\times$ thickness $\times \pi / 6$ ) as described elsewhere (21); all thyroid nodules were identified, localized, counted and their diameters measured. CFDS images were obtained by transverse and longitudinal plane scanning and colour gain was adjusted to avoid artefacts with the probe repetition frequency at $750 \mathrm{~Hz}$. The blood flow was visualized by red and blue spots indicating the direction of flow toward (red) and away (blue) from the transducer. Quantitative flow evaluation was carried out by measuring (mean of four or five samplings at the parenchymal and nodular level) the maximal peak systolic velocity (PSV) of intrathyroid arteries. The CFDS patterns were classified as previously reported (22). Pattern 0: absent intraparenchymal (or nodular) vascularity or minimal spots; pattern I: patchy uneven intraparenchymal colour Doppler signal distribution (only peripheral in the case of nodules); pattern II: mild increase in CFD signal with patchy distribution (for nodules: mainly peripheral); pattern III: markedly increased CFD signal with diffuse homogeneous distribution, including the 'thyroid inferno' (14) (for nodules: intranodular and peripheral vascularity).

\section{Assays}

All hormone and antibody assays were carried out using commercial kits. FT4 and FT3 were assayed by
RIA (Technogenetics, Milan, Italy); TSH by ultrasensitive chemoluminescence assay (Ortho Clinical Diagnostic SpA, Milan, Italy); TSH receptor antibodies (TRAb) by radioreceptor assay (RADIM SpA, Pomezia, Italy); anti-thyroglobulin antibodies (anti-Tg) and anti-thyroid microsomal antibodies (anti-M) by passive haemagglutination (Serodia-ATG and Serodia-AMC, Fujirebio, Tokyo, Japan); and anti-thyroperoxidase antibody (anti-TPO) by RIA (Biocode, Liège, Belgium). Normal values were as follows: FT4, 8.4-20.4 pmol/l; FT3, 4.3-8.6 pmol/l; TSH, 0.2-3.0 mU/l; anti-Tg, negative; anti-M, negative; anti-TPO, <20 U/ml; TRAb, < $10 \mathrm{U} / \mathrm{l}$.

\section{Thyroid scintiscan}

Thyroid scintigraphy was performed by means of a computerized gamma camera equipped with a pinhole collimator (Elscint, SP4; Haifa, Israel) $30 \mathrm{~min}$ after i.v. injection of $110 \mathrm{MBq}\left[{ }^{99 \mathrm{~m}} \mathrm{Tc}\right]$ pertechnetate. The scan was performed in anterior, left-anterior oblique and rightanterior oblique projections. The scintigraphic patterns were categorized into pattern A (uneven, patchy radionuclide distribution) and pattern $B$ (localized uptake in multiple discrete nodules) (8), by two of us (MP, AS) who were unaware of the sonographic results.

\section{Statistical analysis}

Quantitative data are expressed as means \pm s.D. and comparison between means was evaluated using Student's $t$-test.

\section{Results}

\section{Conventional sonography and CFDS results}

The results obtained with conventional sonography and CFDS in the study groups are summarized in Table 2. Hyperthyroid patients of Group A (Graves' disease) displayed diffuse hypoechogenicity with CFDS pattern III and markedly increased parenchymal PSV. Patients of Group B (toxic multinodular goitre) 


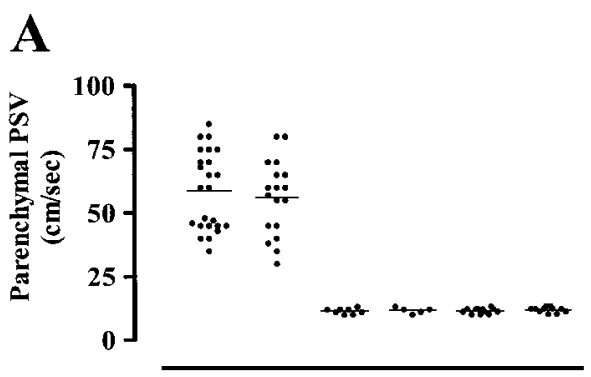

B
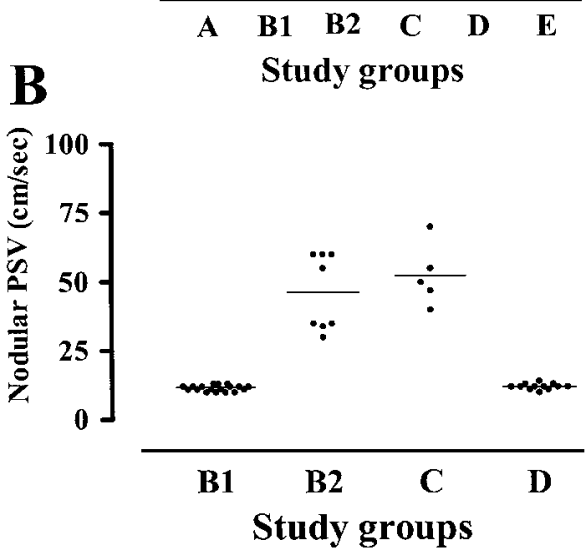

Figure 1 Thyroid parenchymal $(A)$ and nodular $(B)$ maximal PSV observed in individual patients of the different study groups. The horizontal lines represent mean values; for statistical differences between groups see text and Table 2 .

displayed two distinct CFDS patterns: the first (Group B-1) with extranodular parenchyma showing the same characteristics found in Group A and nodules with a CFDS pattern 0-I; the second (Group B-2) displayed two or more nodules with both perinodular and intranodular vascularization (CFDS pattern III). The echogenic structure of these nodules was very heterogeneous, being mostly solid with cystic areas of variable size and macroscopic calcifications. In patients of Group B-2 several mixed/solid nodules with CFDS pattern 0-I were also observed; these nodules were generally smaller and less heterogeneous than those with CFDS pattern III. All patients of Group C (single toxic adenoma) showed a CFDS pattern III within the nodule, with an extranodular parenchymal pattern 0 . No alterations of nodular and extranodular CFDS patterns were observed in Group D patients (non-toxic multinodular goitre). The individual values of PSV found in nodules and extranodular parenchyma are reported in Fig. 1.

\section{CFDS pattern in hyperthyroid patients: relation to TRAb and thyroid autoimmunity}

As shown in Table 1, a similar proportion of thyroid ophthalmopathy, TRAb and other thyroid autoantibody prevalence was found in patients from Group A and B-1, while no evidence of thyroid ophthalmopathy and negative TRAb, anti-Tg, anti-M and anti-TPO were consistently found in all patients of Group B-2 and C. The comparison of individual clinical and immunological data of patients with toxic multinodular goitre from Groups B-1 and B-2 is detailed in Table 3.

\section{Thyroid scintiscan pattern in toxic multinodular goitres: relation to TRAb and thyroid autoimmunity}

Group B patients with toxic multinodular goitre were then subdivided according to their scintigraphic patterns. The comparison of the individual clinical and immunological features of the two scintigraphic subgroups is detailed in Table 4. As expected, the prevalence of thyroid autoimmunity markers was higher in patients with scintiscan pattern A (diffuse uneven radionuclide distribution), but one hyperthyroid patient with positive serum thyroid autoantibodies and one with clear active Graves' ophthalmopathy showed a scintigraphic pattern of localized uptake.

\section{Comparison of CFDS and scintiscan in toxic multinodular goitre}

The prevalence of scintigraphic patterns in patients from CFDS-defined Groups B-1 and B-2 is reported in Fig. 2. The large majority (16 out of $18=89 \%$ ) of patients with increased extranodular vascularity (B-1) displayed diffuse uneven uptake (pattern scan A), while localized uptake (pattern scan B) was observed in the remaining two patients. In patients with increased nodular vascularity (B-2), seven out of eight $(87.5 \%)$ displayed localized uptake, while in the remaining case a diffuse uneven uptake was observed.

\section{Discussion}

The CFDS patterns observed in untreated hyperthyroid patients with Graves' disease and diffuse goitre were in keeping with several previous studies showing that an hypoecogenic thyroid parenchyma with markedly increased blood flow (CFDS pattern III) is a hallmark of this disease $(13,14,16-19)$. The results obtained in hyperthyroid patients with single toxic adenoma displayed a pattern of increased nodular vascularization (CFDS pattern III) on a background of a perinodular parenchyma with normal vascular flow. Again, this finding is in keeping with previous studies showing that increased vascularization is consistently found in autonomous 'hot' thyroid nodules $(13,20)$, being observed even in pre-toxic conditions, before the complete suppression of serum TSH concentrations (20).

When CFDS patterns observed in hyperthyroid patients with multinodular goitres were analysed, two clearly different combinations were observed. The first 
Table 3 Clinical and immunological data of patients with toxic multinodular goitre.

\begin{tabular}{|c|c|c|c|c|c|c|c|}
\hline $\begin{array}{l}\text { Echo } \\
\text { pattern }\end{array}$ & $\begin{array}{l}\text { Patient } \\
\text { no. }\end{array}$ & $\begin{array}{c}\text { Age } \\
(\mathrm{M} / \mathrm{F})\end{array}$ & $\begin{array}{c}\text { Graves' } \\
\text { ophthalmopathy }\end{array}$ & $\begin{array}{c}\text { Anti-M } \\
\text { (n.v. }<1: 100)\end{array}$ & $\begin{array}{c}\text { Anti-Tg } \\
(\text { n.v. }<1: 100)\end{array}$ & $\begin{array}{c}\text { Anti-TPO } \\
\text { (n.v. }<20 \mathrm{U} / \mathrm{ml})\end{array}$ & $\begin{array}{c}\text { TRAb } \\
\text { (n.v. }<10 \mathrm{U} / \mathrm{l})\end{array}$ \\
\hline \multirow[t]{18}{*}{$B-1^{a}$} & 1 & $56(F)$ & + & 1:400 & 1.100 & 13 & 38 \\
\hline & 2 & $66(F)$ & - & 1:6400 & 1:6400 & 227 & 11 \\
\hline & 3 & $60(\mathrm{~F})$ & - & $1: 102400$ & $1: 102400$ & $>2000$ & 10 \\
\hline & 4 & 61 (M) & - & $\mathrm{N}$ & $\mathrm{N}$ & 9 & 9 \\
\hline & 5 & $59(\mathrm{~F})$ & - & $\mathrm{N}$ & $\mathrm{N}$ & 8 & 17 \\
\hline & 6 & $41(\mathrm{~F})$ & - & $1: 400$ & $\mathrm{~N}$ & 83 & 12 \\
\hline & 7 & $35(F)$ & - & $\mathrm{N}$ & $\mathrm{N}$ & 8 & 2 \\
\hline & 8 & $42(F)$ & - & 1:1600 & $\mathrm{N}$ & 113 & 15 \\
\hline & 9 & $58(F)$ & - & $\mathrm{N}$ & $\mathrm{N}$ & 10 & 7 \\
\hline & 10 & $63(F)$ & - & $1: 102400$ & $1: 100$ & 1902 & 14 \\
\hline & 11 & $55(\mathrm{~F})$ & - & $\mathrm{N}$ & $\mathrm{N}$ & 7 & 0 \\
\hline & 12 & $42(\mathrm{~F})$ & - & $\mathrm{N}$ & $\mathrm{N}$ & 7 & 8 \\
\hline & 13 & $47(\mathrm{~F})$ & + & 1:6400 & 1:6400 & 840 & 1 \\
\hline & 14 & $55(\mathrm{~F})$ & - & $1: 6400$ & $\mathrm{~N}$ & 551 & 7 \\
\hline & 15 & 74 (M) & + & $\mathrm{N}$ & $\mathrm{N}$ & 7 & 3 \\
\hline & 16 & $45(F)^{\prime}$ & + & $\mathrm{N}$ & $\mathrm{N}$ & 9 & 8 \\
\hline & 17 & $45(\mathrm{~F})$ & - & $1: 102400$ & $1: 102400$ & $>2000$ & 67 \\
\hline & 18 & $34(\mathrm{~F})$ & - & $1: 102400$ & $\mathrm{~N}$ & 74 & 5 \\
\hline \multirow[t]{8}{*}{$B-2^{b}$} & 1 & $68(F)$ & - & $\mathrm{N}$ & $\mathrm{N}$ & 9 & 1 \\
\hline & 2 & $53(\mathrm{~F})$ & - & $\mathrm{N}$ & $\mathrm{N}$ & 10 & 2 \\
\hline & 3 & $26(F)$ & - & $\mathrm{N}$ & $\mathrm{N}$ & 9 & 3 \\
\hline & 4 & $54(F)$ & - & $\mathrm{N}$ & $\mathrm{N}$ & 10 & 2 \\
\hline & 5 & 71 (M) & - & $\mathrm{N}$ & $\mathrm{N}$ & 6 & 8 \\
\hline & 6 & $68(F)^{\prime}$ & - & $\mathrm{N}$ & $\mathrm{N}$ & 1 & 6 \\
\hline & 7 & $76(F)$ & - & $\mathrm{N}$ & $\mathrm{N}$ & 7 & 0 \\
\hline & 8 & 52 (M) & - & $\mathrm{N}$ & $\mathrm{N}$ & 6 & 1 \\
\hline
\end{tabular}

a Extranodular parenchyma CFD sonography pattern III.

${ }^{\mathrm{b}}$ Peri- and intranodular CFD sonography pattern III.

n.v. = normal value; $\mathrm{N}=$ normal.

was characterized by nodules with normal vascularization (CFDS patterns 0-I) surrounded by hypoechogenic thyroid tissue with markedly increased blood flow showing the same characteristics of diffuse toxic goitre; the second by two or more heterogeneous nodules with increased blood flow (CFDS pattern III), often accompanied by mixed/solid normovascular nodules, within a normoechogenic normovascular parenchyma. The majority of patients with toxic multinodular goitre with hypoechogenic, hypervascularized extranodular parenchyma displayed evidence of associated autoimmunity such as positive serum TRAb and other thyroid autoantibodies and/or unequivocal Graves' ophthalmopathy. In contrast, none of the hyperthyroid patients with toxic multinodular goitre showing increased nodular vascularity had positive serum TRAb and/or other thyroid autoantibodies, or presented clinical evidence of Graves' ophthalmopathy. These results strongly support the concept that the CFDS pattern allows discrimination between an 'autoimmune' form of toxic multinodular goitre (actually Graves' disease developed within a non-toxic multinodular goitre) corresponding to our study Group B-1, from a non-autoimmune form due to multiple autonomous nodules.

In contrast to iodine-sufficient countries, where classical Graves' disease with diffuse goitre represents the most common cause of hyperthyroidism, toxic multinodular goitres are particularly frequent in iodine-deficient populations $(23,24)$. This may be due to progressive development of autonomous thyroid tissue (25-29) or to superimposed autoimmune (TSAb) stimulation $(11,30)$. To differentiate the two forms of toxic multinodular goitre, Kraiem et al. (8) employed the same clinical and serological criteria used by us, while the morphological and functional thyroid evaluation was performed by scintiscan. In their hands, the autoimmune variant of toxic multinodular goitre was frequently associated with a scintigraphic pattern (called pattern A) of diffuse, but uneven (patchy) radionuclide distribution, while the typical scintigraphic pattern of the non-immunogenic variant was represented by multiple discrete 'hot' nodules of varying size and activity (pattern B). The morphological discrimination, however, was not complete, with some patients showing one or more markers of thyroid autoimmunity included in pattern $B$ and vice versa.

In the present investigation we obtained very similar results when patients with toxic multinodular goitre were analysed according to their thyroid scans. The comparison of thyroid CFDS and thyroid scintigraphy in the same patients showed that, as expected, the scintigraphic pattern A corresponded in most cases to 
Table 4 Clinical and immunological data of patients with toxic multinodular goitre.

\begin{tabular}{|c|c|c|c|c|c|c|c|}
\hline Scintiscan & $\begin{array}{c}\text { Patient } \\
\text { no. }\end{array}$ & $\begin{array}{l}\text { Age } \\
(\mathrm{M} / \mathrm{F})\end{array}$ & $\begin{array}{c}\text { Graves' } \\
\text { ophthalmopathy }\end{array}$ & $\begin{array}{c}\text { Anti-M } \\
\text { (n.v. }<1: 100)\end{array}$ & $\begin{array}{c}\text { Anti-Tg } \\
\text { (n.v. }<1: 100)\end{array}$ & $\begin{array}{c}\text { Anti-TPO } \\
\text { (n.v. }<20 \mathrm{U} / \mathrm{ml} \text { ) }\end{array}$ & $\begin{array}{c}\text { TRAb } \\
\text { (n.v. }<10 \mathrm{U} / \mathrm{l})\end{array}$ \\
\hline$A^{a}$ & $\begin{array}{r}1 \\
2 \\
3 \\
4 \\
5 \\
6 \\
7 \\
8 \\
9 \\
10 \\
11 \\
12 \\
13 \\
14 \\
15 \\
16 \\
17\end{array}$ & $\begin{array}{l}56(\mathrm{~F}) \\
52(\mathrm{M}) \\
60(\mathrm{~F}) \\
61(\mathrm{M}) \\
59(\mathrm{~F}) \\
41(\mathrm{~F}) \\
35(\mathrm{~F}) \\
42(\mathrm{~F}) \\
58(\mathrm{~F}) \\
66(\mathrm{~F}) \\
55(\mathrm{~F}) \\
42(\mathrm{~F}) \\
47(\mathrm{~F}) \\
55(\mathrm{~F}) \\
45(\mathrm{~F}) \\
34(\mathrm{~F}) \\
45(\mathrm{~F})\end{array}$ & $\begin{array}{l}+ \\
- \\
- \\
- \\
- \\
- \\
- \\
- \\
- \\
- \\
- \\
- \\
+ \\
- \\
- \\
- \\
+\end{array}$ & $\begin{array}{c}1: 400 \\
N \\
1: 102400 \\
N \\
N \\
1: 400 \\
N \\
1: 1600 \\
N \\
1: 6400 \\
N \\
N \\
1: 6400 \\
1: 6400 \\
1: 102400 \\
1: 102400 \\
N\end{array}$ & $\begin{array}{c}1.100 \\
N \\
1: 102400 \\
N \\
N \\
N \\
N \\
N \\
N \\
1: 6400 \\
N \\
N \\
1: 6400 \\
N \\
1: 102400 \\
N \\
N\end{array}$ & $\begin{array}{r}13 \\
7 \\
>2000 \\
9 \\
8 \\
83 \\
8 \\
113 \\
10 \\
227 \\
7 \\
7 \\
840 \\
551 \\
>2000 \\
74 \\
9\end{array}$ & $\begin{array}{r}38 \\
1 \\
10 \\
9 \\
17 \\
12 \\
2 \\
15 \\
7 \\
11 \\
0 \\
8 \\
1 \\
7 \\
67 \\
5 \\
8\end{array}$ \\
\hline $\mathrm{B}^{\mathrm{b}}$ & $\begin{array}{l}1 \\
2 \\
3 \\
4 \\
5 \\
6 \\
7 \\
8 \\
9\end{array}$ & $\begin{array}{l}68(\mathrm{~F}) \\
53(\mathrm{~F}) \\
26(\mathrm{~F}) \\
54(\mathrm{~F}) \\
71(\mathrm{M}) \\
68(\mathrm{~F}) \\
76(\mathrm{~F}) \\
63(\mathrm{~F}) \\
74(\mathrm{M})\end{array}$ & $\begin{array}{l}- \\
- \\
- \\
- \\
- \\
- \\
- \\
- \\
+\end{array}$ & $\begin{array}{c}N \\
N \\
N \\
N \\
N \\
N \\
N \\
1: 102400 \\
N\end{array}$ & $\begin{array}{c}N \\
N \\
N \\
N \\
N \\
N \\
N \\
1: 100 \\
N\end{array}$ & $\begin{array}{r}9 \\
10 \\
9 \\
10 \\
6 \\
1 \\
7 \\
1902 \\
7\end{array}$ & $\begin{array}{r}1 \\
2 \\
3 \\
2 \\
8 \\
6 \\
0 \\
14 \\
3\end{array}$ \\
\hline
\end{tabular}

${ }^{a}$ Diffuse but uneven radionuclide distribution.

${ }^{\mathrm{b}}$ Localized technetium uptake in multiple discrete nodules.

n.v. $=$ normal values. $\mathrm{N}=$ normal.

goitres with increased extranodular blood flow, while the scintigraphic pattern B was mostly found in patients with increased nodular vascularization. The correspondence between the scintigraphic and the CFDS patterns was not absolute with 3 out of $26(11.5 \%)$

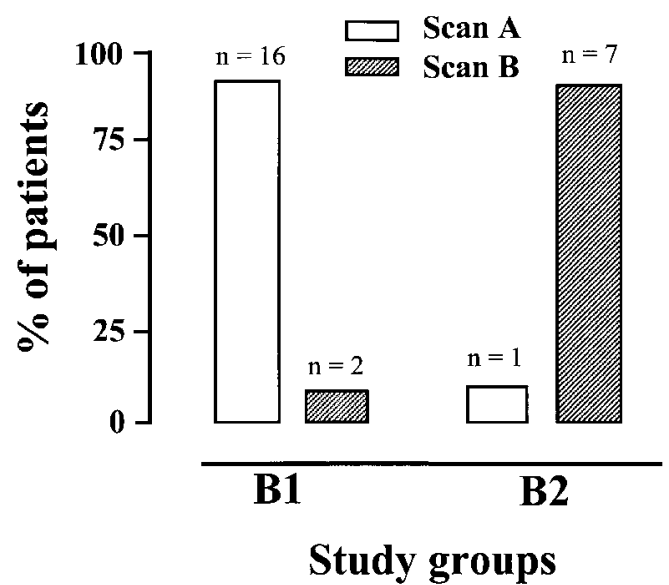

Figure 2 Comparison of CFDS and scintiscan patterns in patients with toxic multinodular goitre. Group B-1 includes patients with increased thyroid parenchymal vascularity; Group B-2 includes those with increased nodular vascularity. Scan $A$ indicates diffuse but uneven radionuclide distribution and scan $B$ localized uptake in multiple discrete nodules. patients showing a mismatch. The analysis of the clinical and biochemical features of the individual patients (see Tables 3 and 4) suggested that CFDS provided a discrimination between autoimmune and non-immunogenic variants of toxic multinodular goitre possibly better than ${ }^{99 \mathrm{~m}} \mathrm{Tc}$ scintigraphy. We are aware, however, that it is difficult from our present results to fully compare the sensitivity and specificity of thyroid CFDS with thyroid scintigraphy in the diagnostic evaluation of toxic multinodular goitre. For example, it is conceivable that the use of radioiodine could have provided slightly different results, because this radionuclide is a more 'physiological' thyroid substrate than ${ }^{99 \mathrm{~m}} \mathrm{Tc}$ and discrepant radioiodine $/{ }^{99 \mathrm{~m}} \mathrm{Tc}$ scans have been occasionally reported in thyroid nodular diseases $(31,32)$. Nevertheless, our data provide further evidence that the CFDS technique is a very sensitive and specific method to precisely identify hyperfunctioning thyroid tissue. Moreover, our finding of increased blood flow strictly limited to the hyperfunctioning thyroid tissue (extranodular parenchyma or nodules) provides further evidence for the concept that increased vascularization is due to primary thyroid tissue hyperfunction and is not affected by the increased circulating thyroid hormone concentration per se (22). Further studies are needed to ascertain whether and to what extent other potential causes of increased 
vascularity in thyroid nodules (e.g. high proliferative potential such as malignant tumours (33) coincidentally present in toxic goitres $(34,35))$ might confound the CFDS pattern in individual patients.

In conclusion, this study shows that combined conventional sonography and CFDS may easily distinguish in most cases nodular variants of Graves' disease from non-immunogenic forms of toxic multinodular goitre and confirms the clinical usefulness of this technique in the first-line evaluation of hyperthyroid patients.

\section{Acknowledgements}

This work was partially supported by MURST (Rome, Italy) and by funds of Regione Autonoma Sardegna to the Centro Studio per la Prevenzione e Terapia delle Malattie della Tiroide. The skilled technical assistance of Mr A Taberlet is also acknowledged.

\section{References}

1 Marine D \& Lenhart CH. Pathological anatomy of exophthalmic goitre. Archives of Internal Medicine 19118 256-316.

2 Charkes ND. Graves' disease with functioning nodules (MarineLenhart syndrome). Journal of Nuclear Medicine 197213885 892.

3 Brown RS, Jackson IM, Pohl SL \& Reichlin S. Do thyroidstimulating immunoglobulins cause non-toxic and toxic multinodular goitre? Lancet $19781904-906$.

4 Bolk JH, Elte JW, Bussemaker JK, Haak A \& van der Heide D. Thyroid-stimulating immunoglobulins do not cause nonautonomous, autonomous, or toxic multinodular goitres. Lancet $1979261-63$

5 Smyth PP, Neylan D \& O'Donovan DK. The prevalence of thyroid-stimulating antibodies in goitrous disease assessed by cytochemical section bioassay. Journal of Clinical Endocrinology and Metabolism 198254 357-361.

6 Wiener JD \& van der Gaag RD. Autoimmunity and the pathogenesis of localized thyroid autonomy (Plummer's disease). Clinical Endocrinology 198523 635-642.

7 Grubeck-Loebenstein B, Derfler K, Kassal H, Knapp W, Krisch K, Liszka $\mathrm{K}$ et al. Immunological features of nonimmunogenic hyperthyroidism. Journal of Clinical Endocrinology and Metabolism $198560150-155$

8 Kraiem Z, Glaser B, Yigla M, Pauker J, Sadeh O \& Sheinfeld M. Toxic multinodular goiter: a variant of autoimmune hyperthyroidism. Journal of Clinical Endocrinology and Metabolism $198765659-664$.

9 van Soestbergen MJ, van der Vijver JC \& Graafland AD. Recurrence of hyperthyroidism in multinodular goiter after long-term drug therapy: a comparison with Graves' disease. Journal of Endocrinological Investigation 199215 797-800.

10 Smith BR, McLachlan SM \& Furmaniak J. Autoantibodies to the thyrotropin receptor. Endocrine Reviews 19889 106-121.

11 Vitti P, Chiovato L, Tonacchera M, Bendinelli G, Mammoli C, Capaccioli A et al. Failure to detect thyroid growth-promoting activity in immunoglobulin $\mathrm{G}$ of patients with endemic goiter. Journal of Clinical Endocrinology and Metabolism 199478 10201025.

12 Larsen PR \& Ingbar SH. The thyroid gland. In Williams' Textbook of Endocrinology, edn 8, pp 357-487. Eds JD Wilson \& DW Foster. Philadelphia: Saunders, 1992.

13 Summaria V, Salvatori M, Rufini V, Mirk P, Garganese MC \& Romani M. Diagnostic imaging in thyrotoxicosis. Rays 199924 273-300.
14 Ralls PW, Mayekawa DS, Lee KP, Colletti PM, Radin DR, Boswell WD et al. Color-flow Doppler sonography in Graves' disease: 'thyroid inferno'. American Journal of Roentgenology 1988150 781-784.

15 Vitti P, Rago T, Mazzeo S, Brogioni S, Lampis M, De Liperi A et al. Thyroid blood flow evaluation by color-flow Doppler sonography distinguishes Graves' disease from Hashimoto's thyroiditis. Journal of Endocrinological Investigation 199518 857-861.

16 Vitti P, Rago T, Mancusi F, Pallini S, Tonacchera M, Santini F et al. Thyroid hypoechogenic pattern at ultrasonography as a tool for predicting recurrence of hyperthyroidism after medical treatment in patients with Graves' disease. Acta Endocrinologica 1992126 $128-131$.

17 Zingrillo M, D’Aloiso L, Ghiggi MR, Di Cerbo A, Chiodini I, Torlontano $\mathrm{M}$ et al. Thyroid hypoechogenicity after methimazole withdrawal in Graves' disease: a useful index for predicting recurrence? Clinical Endocrinology 199645 201-206.

18 Castagnone D, Rivolta R, Rescalli S, Baldini MI, Tozzi R \& Cantalamessa L. Color Doppler sonography in Graves' disease: value in assessing activity of disease and predicting outcome. American Journal of Roentgenology 1996166 203-207.

19 Morosini PP, Simonella G, Mancini V, Argalia G, Lucarelli F, Montironi R et al. Color Doppler sonography patterns related to histological findings in Graves' disease. Thyroid 1998 8 577-582.

20 Becker D, Bair HJ, Becker W, Gunter E, Lohner W, Lerch S et al. Thyroid autonomy with color-coded image-directed Doppler sonography: internal hypervascularization for the recognition of autonomous adenomas. Journal of Clinical Ultrasound 199725 63-69.

21 Fobbe F, Finke R, Reichenstein E, Schleusener H \& Wolf KJ. Appearance of thyroid diseases using colour-coded duplex sonography. European Journal of Radiology 1989 9 29-31.

22 Bogazzi F, Bartalena L, Brogioni S, Burelli A, Manetti L, Tanda ML et al. Thyroid vascularity and blood flow are not dependent on serum thyroid hormone levels: studies in vivo by color flow Doppler sonography. European Journal of Endocrinology 1999140 $452-456$.

23 Laurberg P, Pedersen KM, Hreidarsson A, Sigfusson N, Iversen E \& Knudsen PR. Iodine intake and the pattern of thyroid disorders: a comparative epidemiological study of thyroid abnormalities in the elderly in Iceland and in Jutland, Denmark. Journal of Clinical Endocrinology and Metabolism 199883 765-769.

24 Laurberg P, Pedersen KM, Vestergaard H \& Sigurdsson G. High incidence of multinodular toxic goitre in the elderly population in a low iodine intake area vs high incidence of Graves' disease in the young in a high iodine intake area: comparative surveys of thyrotoxicosis epidemiology in East-Jutland Denmark and Iceland. Journal of Internal Medicine 1991229 415-420.

25 Peter HJ, Gerber H, Studer H \& Smeds S. Pathogenesis of heterogeneity in human multinodular goiter. A study on growth and function of thyroid tissue transplanted onto nude mice. Journal of Clinical Investigation 198576 1992-2002.

26 Studer H, Peter HJ \& Gerber H. Natural heterogeneity of thyroid cells: the basis for understanding thyroid function and nodular goiter growth. Endocrine Reviews 198910 125-135.

27 Tonacchera M, Van Sande J, Parma J, Duprez L, Cetani F, Costagliola $\mathrm{S}$ et al. TSH receptor and disease. Clinical Endocrinology $199644621-633$.

28 Tonacchera M, Chiovato L, Pinchera A, Agretti P, Fiore E, Cetani F et al. Hyperfunctioning thyroid nodules in toxic multinodular goiter share activating thyrotropin receptor mutations with solitary toxic adenoma. Journal of Clinical Endocrinology and Metabolism 199883 492-498.

29 Vassart G, Van Sande J, Parma J, Tonacchera M, Duprez L, Swillens $\mathrm{S}$ et al. Activating mutations of the TSH receptor gene cause thyroid diseases. Annales d'Endocrinologie 199657 50-54.

30 Vitti P, Rotella CM, Valente WA, Cohen J, Aloj SM, Laccetti P et al. Characterization of the optimal stimulatory effects of Graves' monoclonal and serum immunoglobulin $\mathrm{G}$ on adenosine $3^{\prime}, 5^{\prime}$-monophosphate production in FRTL-5 thyroid cells: a 
potential clinical assay. Journal of Clinical Endocrinology and Metabolism 198357 782-791.

31 Shambaugh GE, Quinn JL, Oyasu R \& Freinkel N. Disparate thyroid imaging. Combined studies with sodium pertechnetate Tc99m and radioactive iodine. Journal of the American Medical Association 1974228 866-869.

32 Reschini E, Catania A, Ferrari C, Bergonzi M, Paracchi A \& Raineri P. Comparison of pertechnetate and radioiodine thyroid scintiscans in thyroid disease. Journal of Nuclear Biology and Medicine $19933712-17$.

33 Rago T, Vitti P, Chiovato L, Mazzeo S, De Liperi A, Miccoli P et al. Role of conventional ultrasonography and color flow-Doppler sonography in predicting malignancy in 'cold' thyroid nodules. European Journal of Endocrinology 1998138 41-46.

34 Pacini F, Elisei R, Di Coscio GC, Anelli S, Macchia E, Concetti R et al. Thyroid carcinoma in thyrotoxic patients treated by surgery. Journal of Endocrinological Investigation 198811 107-112.

35 Rieger R, Pimpl W, Money S, Rettenbacher L \& Galvan G. Hyperthyroidism and concurrent thyroid malignancies. Surgery $19891066-10$

Received 21 January 2000

Accepted 12 May 2000 